\title{
The Effect of Online Guest Review, Hotel Facilities and Online Travel Agent Price on Decision to Stay at Grand Rocky Hotel Bukittinggi : The Case of Traveloka
}

\author{
Desy Azulmi ${ }^{1}$, Adinoto Nursiana ${ }^{2}$, Rahmat Ingkadijaya ${ }^{3}$ \\ 1,3 Sekolah Tinggi Pariwisata Trisakti \\ 2Sekolah Tinggi Ilmu Ekonomi Wiyatamandala \\ 1azulmi.desy@gmail.com
}

\begin{abstract}
Technological developments have shifted the behavior of offline bookings to worldwide online booking, including in Indonesia. This country is currently experiencing a significant increase in the number of Online Travel Agents such as Traveloka. In this website, people can see reviews from previous guests on the strengths and weaknesses of the hotel, and it facilitates people to select a hotel matching to their needs and preferences. Previous research proves that online reviews and facilities affect the guest's stay decisions. This research aims to determine the effect of online reviews, hotel facilities and prices on the decision to stay at the Grand Rocky Hotel Bukittinggi. The method used in this research is a qualitative method to obtain comprehensive, valid, reliable and objective data. The sample used in this research were 100 guests who stayed at the Grand Rocky Hotel with the reservation through Traveloka. Sample selection was based on purposive sampling technique, and data collection was conducted by Likert questionnaires to investigate the effect of online reviews, facilities and prices on the decision to stay. The results reveals online reviews, hotel facilities and prices have a strong influence on the decision to stay. Therefore, online reviews, facilities, and competitive prices serve as marketing tools to increase hotel revenues from the Online Travel Agent.
\end{abstract}

Keywords : Online Review, Hotel Facility, Price, Decision to Stay 
The Effect of Online Guest Review, Hotel Facilities and Online Travel Agent Price on

Decision to Stay at Grand Rocky Hotel Bukittinggi : The Case of Traveloka

\section{A. Introduction}

The use of online social network has been commonly adopted in tourism sector in Bukittinggi. These days, Traveloka is one of the Online Travel Agent with the highest number of room selling in Grand Rocky Hotel; a fourstar hotel in Bukittinggi. Traveloka is used as a major tool to get some references when preparing a trip to tourist attraction. In fact, people go to Traveloka website for online reviews, information on hotel facilities, and room rate as references before they make purchasing decision.

Based on researchers' observation, Traveloka is able to sell various rooms per month all through the year, an interesting case research for this research. A research reveals $75 \%$ respondents trust online reviews given by previous guests when making decision to choose a hotel to stay. Besides, these guests' online reviews are adopted as references about facilities, services and competitive price offered by the hotel. (Dohmen.2013).

In 2017, the total number of room selling to Grand Rocky Hotel by Traveloka was 3.608 rooms, while the total number of room selling was to 4.588 rooms. In this case, Traveloka has a significant contribution on the room selling of the hotel. It can be inferred that guest review, hotel facilities and price cited in the Traveloka website help the customer to make a decision to choose Grand Rocky Hotel for leisure or bussines in Bukittinggi.

The purpose of this research to investigate whether there is a significant correlation on online guest review, hotel facilities and price with guest's decision to stay in a hotel. The researchers also seek to find out the how those variables affect the guests' decision to stay at Grand Rocky Hotel, Bukittinggi.

Bukittinggi is one of the best tourist destinations in Indonesia with Jam Gadang as a landmark. The increasing number of tourist visits results in the high room occupancy especially on weekends, school and public holidays. New hotels are established to welcome both domestic and foreign tourists, one of them is the four-star- Grand Rocky Hotel. This phenomenon is one of the impacts of tourism industry which can be felt not only in city centers but also remote areas. A research on the tourism impacts in Gunungkidul points out the positive impacts of tourism in the area of economic, socio-cultural and environmental (Rahayu. 2018)

To address the topic comprehensively, the first part of the literature review focuses on how online reviews are perceived. In the second part we putforward the main hotel facilities with the existence of these online price platforms. Based on the literature review, the research hypotheses are formulated then tested empirically. The quantitative research is based on online guest review, hotel facilities and price online travel agent Traveloka in Grand Rocky Hotel. Finally, the results show that the quantitative reviews, facility and price that appear on Traveloka have influence on the number of guest stay in Grand Rocky Hotel Bukittinggi. 


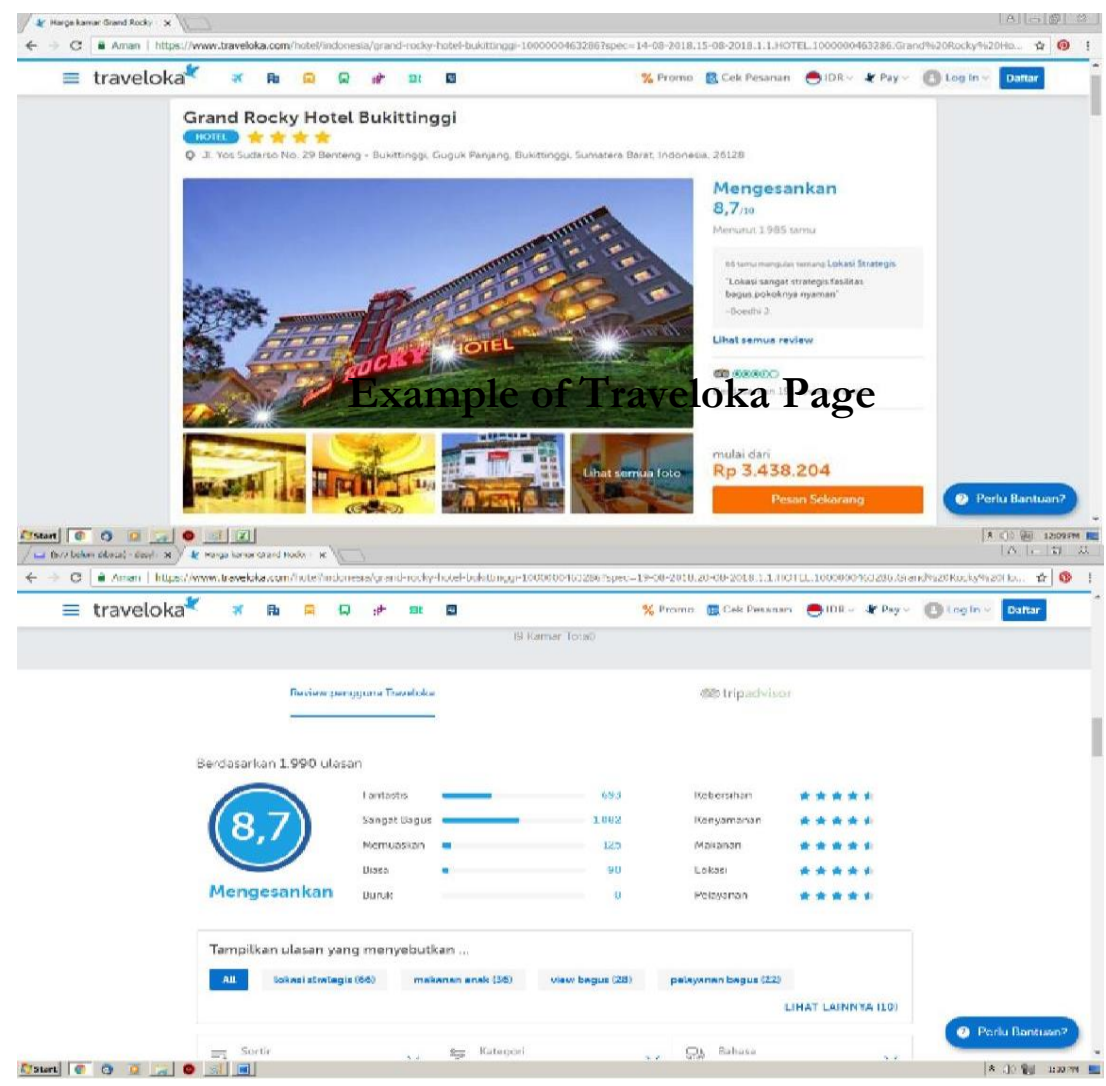

Figure 1 Example of Traveloka Page

\section{B. Literature Review \\ 1. Hotel}

Hotels have a variety of definitions, Hotel Proprietors defines a hotel as a company managed by its owner by providing food, beverage and room facilities for sleeping to people who are traveling and able to pay a reasonable amount in accordance with the service accepted without special agreement (Sulistiyono.2008). The hotel industry is mix of services like accommodation, specialty restaurants, 24X7 cafe, laundry, gym, spa and many more (Sharma and Srivastava, 2018). Based on the definition, the writer concludes that the hotel is a service business which is a means of supporting tourism activities, where the management is carried out professionally and supported by workers who have good skills in hospitality.

\section{Online Guest Review}

Many guests see online reviews as a matter of consideration before making a decision in choosing transportation, accommodation and tourist destinations when going on a tour, they will read positive reviews and negative reviews that the guest previously wrote on the online travel website (Vermeulen et al. 2008) Many things must be considered in the review so that the review 
will be more effective and provide many benefits for people who read it. Zhao et al., (2015) argues that there are 6 online reviews conditions that we must know to be effective, namely:

\section{a. Usefulness of online review}

The use of online review is the extent to which online reviews will facilitate the process of making customer purchase decisions. Usefulness of online review has been proposed as an effective predictor for measuring customer intention to make a purchase

\section{b. Expert reviewer}

Review written in cyberspace / internet, about a product or their experience enjoying facilities and services because they see reviews of other guests who discuss the same thing because guests who wrote before are considered more expertise or experts because they have already experienced the experience

\section{c. Timeliness of online review}

Websites on the internet need to be constantly updated consistently with the aim of providing added value to someone who reads them. As long as someone searches for information, the customer is faced with the amount of information circulating, where there is correct information and incorrect information and the information is arranged in a series of different times, it will affect customers who read.

\section{d. Volume of online review}

It is another attribute of WOM and is a measure of the total number of interactive messages. The number of posts made by reviewers is an attribute of word of mouth because it displays a collection of reviews from all those who made it. Variations in volume of online reviews provide evidence that not all products and services are treated equally; therefore, it is only natural that can not customers are not equal in evaluating a review.

e. Valence of online review

In an online review can provide negative and positive messages simultaneously. The decision-making process is focused on the content of the message, especially customers will pay more attention to negative information as an evaluation of the product or service they enjoy.

f. Comprehensive of online review

The completeness in the online review has a relationship with the online review recommendations themselves and is an advantage to be able to measure how detailed and complete a review is.

Tourism Research Journal, Volume 2 (2), 2018 
The Effect of Online Guest Review, Hotel Facilities and Online Travel Agent Price on

Decision to Stay at Grand Rocky Hotel Bukittinggi : The Case of Traveloka

\section{Hotel Facilities}

Facilities are a means to launch and facilitate the implementation of functions. Facilities are individual components of offerings that are easily grown or reduced without changing the quality and model of services. The facility is also a tool to differentiate one company from another competitor. (Lupiyoadi,2013).

Commercialized or sold facilities must fulfill several conditions because facilities are physical resources that exist before a service can be offered to consumers (Tjiptono, 1997), where the facility provides physical equipment to provide convenience to guests in carrying out their activities or its activities, so that guests' needs can be met during their stay at the hotel.

To determine the level of facilities, there are several indicators consisting of (Oka.A.Yoeti, 2007):

1. Availability

A supporting facility and infrastructure that will be given to guests such as lighting, beds or music. In other words, availability is the readiness of facilities and infrastructure of a company in improving the services that will be provided to guests.

\section{Completeness}

A design tool for a hotel and hotel room consisting of furniture. Furniture equipment used can make a room more attractive and comfortable for guests staying.

\section{Comfort}

A security, comfort and tranquility that guests get during the hotel, making guests comfortable in doing various activities during the hotel. Includes all supporting facilities in the hotel.

\section{Cleanliness}

Cleanliness is a sign of the existence of a clean place or room. Need to protect the environment and cleanliness of hotel rooms, if cleanliness is maintained, guests will become more tenant because sanitation and hotel hygiene are guaranteed.

\section{Price}

This understanding is in accordance with the concept of exchange in marketing. Based on the above understanding, it can be concluded that the price is a sum of money and / or other aspects (non-monetary) used to obtain goods or services. Basically Price is the amount of money paid for goods or services or the amount that consumers exchange in order to get the benefits of owning or using goods and services (Kotler \& Keller, 2009) Price indicator on 
The Effect of Online Guest Review, Hotel Facilities and Online Travel Agent Price on

Decision to Stay at Grand Rocky Hotel Bukittinggi : The Case of Traveloka

this research According to Stanton (2010) there are 3 indicators that define prices, namely:

1) Affordability

Consumers can reach the prices set by the company. Products usually have several types in one brand and the price is also different from the cheapest to the most expensive. With the prices set, consumers can buy products that match their needs.

2) Interest

Consumers decide to buy a product if the perceived benefits are greater or equal to those already issued to get it. If consumers feel the benefits of the product are smaller than the money spent, then consumers will argue that the product is expensive and consumers will think twice about repurchasing.

3) Competitiveness

Consumers often compare the price of a product with other products. In this case, expensive or cheap products are highly considered by consumers when they are going to buy the product.

\section{Decision to stay}

The purchase decision is an integration process that combines the attitude of knowledge to evaluate two or more alternative behaviors, and choose one of them (Nugroho in Sunyoto, 2011). A decision is the selection of two or more alternative choices. In other words alternative choices must be available to someone when making a decision (Schiffman and Kanuk in Husein, 2014). Of the several definitions above it can be concluded that decision making is an action taken by consumers to purchase a product. Therefore, consumer purchasing decisions are a process of selecting one of several alternative solutions to problems with real follow-up. After that the consumer can do the evaluation of choice and then can determine the attitude to be taken next.

\section{Introduction to Problem}

The purchase process begins with the introduction of problems or needs. If the need is known, the consumer will and understands the needs that do not need to be fulfilled immediately or the problem can

be delayed, and the needs must be met immediately. So at this stage the purchasing process begins.

2. Information search

A consumer who knows his needs can or cannot seek further information if the urge for desire is strong, if not strong then the consumer's needs will 
The Effect of Online Guest Review, Hotel Facilities and Online Travel Agent Price on

Decision to Stay at Grand Rocky Hotel Bukittinggi : The Case of Traveloka

only be a mere memory. Consumers may do more searches or immediately actively search for information that underlies their needs.

3. Assessment of alternatives

After searching for as much information as possible, consumers use information to evaluate several alternative brands in a choice structure

\section{Purchase Decisions}

If the decision taken is to buy, the buyer will find a series of decisions regarding the type of purchase, time of purchase, and method of purchase. At this stage consumers actually buy products.

5. Behavior after buying

After buying a product, consumers will experience some level of perceived satisfaction or dissatisfaction, there is a possibility that the buyer has dissatisfaction after making a purchase because it is not in accordance with the wishes or the previous picture, and so on

Based on the framework above the hypothesis that emerges is that online reviews can have a major influence on a hotel, because guest reviews are closely related to online sales for the hotel, where rating indicators in a website in online reviews can increase the number of sales, in a survey shown a ten percent increase in the ranking of an online site, so sales of products also increased by five percent (Bagnera, 2016).

Apart from that travel offline is less desirable because guests are more confident in online reviews in providing recommendations regarding a place or hotel regarding the location, price and service facilities of employees (Dohmen, 2013) then online reviews, facilities and prices include factors that influence the selection of hotels guests will choose to stay overnight (Vermeule, 2008) for their own online purchases $50 \%$ of buyers see a review on the travel agent's website (Compete in Gretzel \& Yoo, 2011). Then the researcher can make the hypothesis in his reserch as follow:

1. H1: Online Review has a positive and significant effect on decision to stay at Grand Rocky Hotel

2. H2: Hotel facilities have a positive and significant effect on decision to stay at the Grand Rocky Hotel

3. H3: Room rates have a positive and significant effect on decision to stay at the Grand Rocky Hotel Bukittinggi

4. H4: Online review, hotel facilities and room rates positively and significantly influence the decision to stay at the Grand Rocky Hotel 
The Effect of Online Guest Review, Hotel Facilities and Online Travel Agent Price on

Decision to Stay at Grand Rocky Hotel Bukittinggi : The Case of Traveloka

\section{Research Methodology}

This type of research is survey research, describes social phenomena and causal relationships between service quality variables with customer loyalty through hypothesis testing or what is also called explanatory research (Singarimbun and Effendi, 2008). Information is collected from guests using a questionnaire, with the units analyzed are guests who stay at Grand Rocky Hotel.

This causal explanatory research can be said as a hypothesis testing research that examines the causal relationship between the variables studied. This research method also aims to provide a description / description in the description to produce constraints or a phenomenon based on relationship models derived from theoretical models. To find out the relationship between several independent variables and the dependent variable then after testing the hypothesis then proceed with testing the relationship model.

\section{Population and Sample}

In this research the population are guest who make reservation through Traveloka for staying at the Grand Rocky Hotel located at the address Jl. Yos Sudarso No.29 Benteng Bukittinggi City, West Sumatra.

The number of sample members is often stated with the expected sample are $100 \%$ representing the population itself, the determination of the sample in this research is the number of guests staying by making a reservation through the Traveloka website at the Grand Rocky Bukittinggi hotel. To obtain the number of samples needed by researchers using the Slovin formula (Kriyantono, 2008).

Respondents selected are guests who stay with reservations through the Traveloka website. Dissemination of the large sample, researchers distributed questionnaires using data summarized daily in hotel reservations. Based on the calculation of the previous Slovin formula obtained results $n=98.20$ and rounded to 100 . The results of the spread by meeting the guest when they check out or check in, the final result is 100 respondent

\section{Instruments}

Data collection techniques used are structured questionnaires. The questionnaire can be in the form of a closed question given to the respondent directly using a Likert scale.

\section{Data Analysis}

In the data processing stage activities are carried out such as designing data structures, coding, editing and data entry. Data is stored using Microsoft Excel. After the data is declared valid, the data is ready to be processed. Data analysis using the SPSS program version 16.00. The estimation results are presented in table form. In detail, the data processing and analysis used are as follows: 
The Effect of Online Guest Review, Hotel Facilities and Online Travel Agent Price on Decision to Stay at Grand Rocky Hotel Bukittinggi : The Case of Traveloka

1. Normality Test

Normality test is done by Kolmogorov Smirnov test using SPSS program 16.00 computer aids with the following conditions:

a. Sig./significance value or probability $\leq 0.05$, distribution is abnormal (asymmetric).

b. Sig./significance value or probability $>0.05$, distribution is normal (symmetrical).

2. Homogeneity test

It is done to see whether the samples from the population have the same characteristics or not. For this test, the Test of Homogeneity of Variances is used. The test criteria are:

a. If the value is significant (Sig) or probability value (p) 50.05 , it can be said that the data comes from a population that has the same variant or data that is homogeneous.

b. If the significant value (Sig) or probability value $(\mathrm{p})<0.05$, it can be said that the data comes from a population that has an unequal variant or the data is not homogeneous.

\section{Linearity Test}

Linearity test aims to determine whether the relationship between variables $\mathrm{X}$ and $\mathrm{Y}$ is linear or not. Linearity testing is done using SPSS program (Statistical product and service solution) version 16.00. Two variables are said to have a linear relationship if the Linearity value is $<0.05$

\section{Result}

\section{a. Multiple Linier Regression}

Table 1 Multiple Linier Regression

\begin{tabular}{l|c|c|r|r|r}
\hline \multirow{2}{*}{ Model } & \multicolumn{2}{|c|}{$\begin{array}{c}\text { Unstandardized } \\
\text { Coefficiants }\end{array}$} & $\begin{array}{c}\text { Unstandardized } \\
\text { Coefficiants }\end{array}$ & $\mathrm{t}$ & \multirow{2}{*}{ Sig } \\
\cline { 2 - 4 } & \multicolumn{1}{c|}{$\mathrm{B}$} & Std Error & Beta & & \\
\hline 1(Constant) & -4.434 & 5.367 & & -.826 & .411 \\
Online Review (X1) & .694 & .122 & .448 & 5.679 & .000 \\
Fasilitas Hotel (X2) & .234 & .100 & .200 & 2.354 & .021 \\
Harga (X3) & .620 & .144 & .321 & 4.290 & .000 \\
\hline Data 2018
\end{tabular}


The Effect of Online Guest Review, Hotel Facilities and Online Travel Agent Price on Decision to Stay at Grand Rocky Hotel Bukittinggi : The Case of Traveloka

\section{b. t- test (partial regression coefficient test)}

Table 2 t-test

\begin{tabular}{l|c|c|c|c|c}
\hline \multirow{2}{*}{ Model } & \multicolumn{2}{|c|}{$\begin{array}{c}\text { Unstandardized } \\
\text { Coefficiants }\end{array}$} & $\begin{array}{c}\text { Unstandardized } \\
\text { Coefficiants }\end{array}$ & \multirow{2}{*}{$\mathrm{t}$} & \multirow{2}{*}{ Sig } \\
\cline { 2 - 4 } & $\mathrm{B}$ & Std Erro & Beta & & \\
\hline 1(Constant) & -4.434 & 5.367 & & -.826 & .411 \\
Online Review (X1) & .694 & .122 & .448 & 5.679 & .000 \\
Fasilitas Hotel (X2) & .234 & .100 & .200 & 2.354 & .021 \\
Harga (X3) & .620 & .144 & .321 & 4.290 & .000 \\
\hline
\end{tabular}

Based on the result, the value of $t$ count $>t$ table $(5.679>1.985)$ or the value of Sig. $<0.05(0.000<0.05)$, meaning that Online Review partially influences the decision to stay at the Grand Rocky Hotel Bukittinggi. The value of $t$ count is positive, meaning that it has a positive effect, that is, increasing online reviews will increase the decision to stay. While the hotel facilities variable because the value of $t$ count $>t$ table $(2.354>1.985)$ or the value of Sig. $<0.05(0.021<0.05)$ means that the Hotel Facilities partially affect the Decision of Staying at the Grand Rocky Hotel Bukittinggi. The value of $t$ count is positive, meaning that it has a positive effect, namely that the Hotel Facilities will increase the Stay Decision. The third is the price variable because the value of $\mathrm{t}$ count $>\mathrm{t}$ table $(4.290>1.985)$ or the value of Sig. $<0.05(0.000<0.05)$, meaning that the price partially influences the decision to stay at the Grand Rocky Hotel Bukittinggi. The value of t count is positive, meaning that it has a positive effect, that is, increasing prices will increase the decision to stay.

\section{c. f-t test (regression coefficient test collected)}

Table 3 f-test

\begin{tabular}{l|r|r|r|r|r}
\hline Model & $\begin{array}{r}\text { Sum of } \\
\text { Square }\end{array}$ & df & Mean Square & $\mathrm{F}$ & sig \\
\hline 1. Regression & 1466.661 & 3 & 488.887 & 42.27 & .000 \\
Residual & 1110.089 & 96 & 11.563 & & \\
Total & 2576.750 & 99 & & & \\
\hline
\end{tabular}

Because F counts $>$ F table $(42,279>2,699)$ the value of Sig. $<0.05$ $(0.000<0.05)$, it means that Online Review, Hotel Facilities, together have a positive effect on the Decision to Stay at Grand Rocky Hotel Bukittinggi.

Tourism Research Journal, Volume 2 (2), 2018 
The Effect of Online Guest Review, Hotel Facilities and Online Travel Agent Price on

Decision to Stay at Grand Rocky Hotel Bukittinggi : The Case of Traveloka

\section{d. Analysis of the coefficient of determination (Adjusted R Square)}

Table 4 R Square

\begin{tabular}{l|l|l|l|l}
\hline Model & $\mathrm{R}$ & R Square & $\begin{array}{l}\text { Adjusted R } \\
\text { Square }\end{array}$ & $\begin{array}{l}\text { Std Error of the } \\
\text { estimate }\end{array}$ \\
\hline $\mathrm{X} 1$ & $.154 \mathrm{a}$ & .024 & .013 & 5.12755 \\
$\mathrm{X} 2$ & $.086 \mathrm{a}$ & .007 & .003 & 5.16986 \\
$\mathrm{X} 3$ & $.051 \mathrm{a}$ & .003 & .008 & 5.18233 \\
Summary & $.754 \mathrm{a}$ & .569 & .556 & 3.401 \\
\hline
\end{tabular}

From the above output, it is known that $\mathrm{R}$ square is 0.024 , this value means that the influence of Guest Online Review (X1) on the Decision of Stay $(\mathrm{Y})$ is $2.4 \%$ while the remaining $97.6 \%$ of the Decision Stay is influenced by other variables. Hotel Facility show that $\mathrm{R}$ square is 0.007 , this value means that the influence of Hotel Facilities (X2) on the Decision of Stay $(\mathrm{Y})$ is $0.7 \%$ while the remaining $99.3 \%$ of the Decision Stay is influenced by other variables. Price give output that $\mathrm{R}$ square is 0.003 , this value means that the influence of Online Travel Agent Price (X3) on the Decision of Stay (Y) is $0.3 \%$ while the remaining $99.7 \%$ of the Decision of Stay is influenced by other variables. Furthermore, to find out the effect of training on performance can be seen in the following table.

Based on the table above, the value of adjusted $\mathrm{R} 2$ is $0.556(55.6 \%)$. This shows that variations in the independent variables used in the model (Online Review, Hotel Facilities, and Prices) are able to explain 55.6\% variation in the decision decision variable, and the rest is explained by other variables not included in this research model.

\section{E. Discussion}

From the above data we can see that the hotel cannot only see and focus on one variable only to increase the number of room sales, especially for room sales through the Online Travel Agent because from the online review variable research only affected $2.4 \%$ of the decision to stay because of guests pay attention to variable facilities that are good and complete and variable prices are also in accordance with the facilities that guests will receive. While the facility variable only affected $0.7 \%$ of the decision to stay because guests saw the online review variables that they would refer to to see if it was in accordance with the variable price they would pay based on positive comments and negative comments on the Traveloka website.

Furthermore, the price variable only affects $0.3 \%$ for purchases because guests will also see online reviews and facilities as a consideration when choosing a hotel. Hotel management must pay attention to these three variables together in terms of improving the facilities provided, competitive prices and providing good services to all guests so that they can reduce the negative review 
The Effect of Online Guest Review, Hotel Facilities and Online Travel Agent Price on

Decision to Stay at Grand Rocky Hotel Bukittinggi : The Case of Traveloka

on the Traveloka website page.

Another thing that researchers found about the effect of the down and up of sales of hotel rooms at the Grand Rocky Hotel Bukittinggi was the existence of two competitor hotels namely the Novotel Hotel and the Grand Royal Denai Hotel. The Novotel hotel which is incorporated in the Accor Group has its own market share in addition to support from other Accor Hotels around the world. In general, guests who already know for certain services and facilities with international standards applied by the Novotel Hotel will choose the hotel when visiting Bukittinggi. The second is Grand Royal Denai Hotel, a hotel that has only been operating for 2 years gives many promo prices to guests as a means of promoting their hotel introduction in addition to the guests' own wishes to try a new hotel with the latest facilities as well.

\section{F. Conclusion}

After analyzing and observing all existing limitations, the researchers gave advice to the management of the Grand Rocky Bukittinggi hotel

1. Based on the results of the research suggested to the Grand Rocky hotel management to be able to maximize promotion with online media, because of the existing online media such as websites, Facebook and Instagram it has not been used optimally. This is considered important by the researchers because what is displayed by the hotel management on the online link can be accessed by prospective guests who are looking for hotel references in the Bukittinggi area. This can reduce the selling price of Grand Rocky Hotel.

2. The researcher recommends updating information on the Online Travel Agent periodically not only at the price that is updated every day but the facility information can be updated periodically by replacing the photos that are displayed so that the facilities provided by the hotel can be accessed more clearly by guests.

3. The hotel cannot pay attention to the three variables individually because it does not show a large influence on increasing the sales of hotel rooms but must pay attention to the three online review variables, facilities and prices in online room purchase decisions because the aspects that have a big influence are when these three aspects jointly influence the decision of the guest in choosing a hotel to stay. 
The Effect of Online Guest Review, Hotel Facilities and Online Travel Agent Price on Decision to Stay at Grand Rocky Hotel Bukittinggi : The Case of Traveloka

\section{REFERENCES}

A. Yoeti, Oka (1997). Perencanaan dan Pengembangan Pariwisata . PT. Pradya Paramitha. Jakarta.

Bagnera,Suzanne. (2011). An Examination of Online Ratings on Hotel Performance Indicators: An Analysis of The Boston Hotel Market. Boston University

Dohmen,Anouk. (2013). Determining the Important of and preference for types of online Travel Recommendations. Tesis. Erasmus University. Rotterdam

E. Vermeulen*, Daphne Seegers. (2008). Tried and tested: The impact of online hotel reviews on consumer Consideration Ivar

Fandy Tjiptono. (2000). Marketing Scale. Yogyakarta:Andi

Gretzel, U., \& Yoo, K. H (2008). Use and impact of online travel reviews. Information and Communication Technologies in Tourism 2008 Proceedings of the International Conference in Innsbruck, 35-46.

Husein Umar. (2014). Metode Penelitian Untuk Skripsi dan Tesis Bisnis. Edisi2. Cetakan ke-13. Jakarta : Rajawali Pers.

Kotler and Keller. (2009). Marketing Management Jilid 2. New Jersey : Prentice Hall Inc

Kotler, Philip (2004). Prinsip-prinsip Pemasaran, edisi 12 , Jilid 2 . Jakarta : Erlangga

Kriyantono, Rachmat. (2208). Teknik Praktis Riset Komunikasi. Kencana Prenada Media Group.

Lupiyoadi, Rambat. (2013). Management Pemasaran Jasa Berbasis Kompetensi.Jakarta.Salemba Empat.

Rahayu, Nurti. (2018). Residents' Place Image and Perceived Tourism Impacts in Gunungkidul, Yogyakarta Special Region. In 2nd International Conference on Tourism, Gastronomy, and Tourist Destination (ICTGTD 2018). Atlantis Press.

Rambat Lupiyoadi. (2006). Management Pemasaran Jasa (Teori dan raktek). Edisi pertama. Salemba Empat,Depok

Sharma, Shavita and Sidharth Srivastava. (2018). Relationship Between Service Quality and Customer Satisfaction in Hotel Industry. Tourism Research Journal. 2 (1), 42 - 49.

Singarimbun, Masri., and Sofian Effendi. (2008). Metode Penilaian Survei. Pustaka LP3ES. Jakarta.

Slovin dalam Umar,H. (2003). Riset Pemasaran dan Prilaku Konsumen. Jakarta.Gramedia Pustaka

Sulistiyono,Agus. (2006). Manajemen Penyelengaraan Hotel.Seri Manajemen Usaha Sarana Prasarana Pariwisata dan Akomodasi. Alfabeta CV. Bandung 
The Effect of Online Guest Review, Hotel Facilities and Online Travel Agent Price on Decision to Stay at Grand Rocky Hotel Bukittinggi : The Case of Traveloka

Sulistiyono,Agus. (2006). Manajemen Penyelengaraan Hotel.Seri Manajemen Usaha Sarana Prasarana Pariwisata dan Akomodasi.; Tehnik dan Prosedure Divisi Kamar.Alfabeta CV. Bandung

Sunyoto, Danang. (2011). Metodelogi Penelitian untuk Ekonomi. CAPS. Yogyakarta

Stanton, William,J. (2002).Fundamental of Marketing.Mc Graw \& Co New York.

Zhao et al. (2015). The influence of online reviews to online hotel booking intentions. International Journal of Contemporary Hospitality Management, vol 27 no 6, 1343-1364. 